\title{
Biomass and essential oil production from menthe is influenced by compost and lime
}

\author{
Patricia Alves Casaes Alves ${ }^{1}$, Eduardo Gross ${ }^{2 *}$, Larissa Corrêa do Bomfim Costa ${ }^{3}$, Verônica \\ Cordeiro Silva ${ }^{1}$, Fábio Mathias Corrêa ${ }^{4}$ and Rosilene Aparecida de Oliveira ${ }^{4}$ \\ ${ }^{1}$ Programa de Pós-graduação de Produção Vegetal, Universidade Estadual de Santa Cruz, Rodovia Jorge Amado km \\ 16, Ilhéus, Bahia, Brazil. \\ ${ }^{2}$ Departamento de Ciências Agrárias e Ambientais, Universidade Estadual de Santa Cruz, Rodovia Jorge Amado km 16, \\ Ilhéus, Bahia, Brazil. \\ ${ }^{3}$ Departamento de Ciências Biológicas, Universidade Estadual de Santa Cruz, Rodovia Jorge Amado km 16, Ilhéus, \\ Bahia, Brazil. \\ ${ }^{4}$ Departamento de Ciências Exatas e Tecnológicas, Universidade Estadual de Santa Cruz, Rodovia Jorge Amado km \\ 16, Ilhéus, Bahia, Brazil.
}

Received 27 August, 2013; Accepted 14 March, 2014

\begin{abstract}
As a product of secondary metabolism, essential oils may exhibit variation in their composition according to mode of plant cultivation. The application of organic manure has been considered one of the key factors for increasing biomass and essential oil production in most of medicinal plants, as it provides nutrients and increases their uptake. This study aimed to evaluate the influence of organic fertilizer and lime doses on the biomass production of Mentha arvensis, as well as the content, yield and chemical composition of its essential oil. The experiment was conducted in a greenhouse and was performed according to a double factorial design consisting of four doses of dolomitic limestone $(0.0$, $0.25,2.0$ and $3.72 \mathrm{~g} \mathrm{dm}^{-3}$, corresponding to $\mathrm{a} \mathrm{pH}$ of $4,5,6$ and 7 , respectively) and five doses of the organic compost $\left(0,5,10,20\right.$ or $\left.40 \mathrm{~g} \mathrm{dm}^{-3}\right)$ with ten replicates. There was an interaction between organic fertilization and liming for biomass production, with maximum leaf biomass averaged $8.61 \mathrm{~g} \mathrm{plant}^{-1}$ and essential oil yield with application of 26 to $29 \mathrm{~g} \mathrm{dm}^{-3}$ of organic compost and 1.7 to $2.0 \mathrm{~g} \mathrm{dm}^{-3} \mathrm{of}$ limestone into soil. Neo-iso-menthol was the major component of the $M$. arvensis essential oil.
\end{abstract}

Key words: Limestone, organic manure, neo-iso-mentol, Japanese mint, organic production.

\section{INTRODUCTION}

Fertilization is extremely important for obtaining high yields in most crops. On the other hand, intensive farming systems with fertilizer-responsive crops that have a high demand for inorganic fertilizers often lead to non- sustainable production and can also cause a serious threat to soil health (Hendawy, 2008). In recent years, the world has been growing increasingly concerned with environmental and health issues. The desire for 
conservation has resulted in the search for technologies by the productive sector for the implementation of sustainable organic production systems. The use of organic nutrient sources with little or no use of inorganic fertilizers is being adopted due to a positive influence on the biological processes of decomposition and mineralization of organic matter, which provide the soil with greater resilience and buffering capacity (Karlen et al., 1992).

Organic fertilizer provides nutrients and is considered one of the key factors for increased biomass production, and especially for the quality of essential oil in medicinal plants, as well as being safer for human and animal health and the environment, providing benefits in the form of improvements in physical, chemical and biological soil properties (Priyadarshani et al., 2013; Rosal et al., 2011; Al-Fraihat et al., 2011 Brant et al., 2010; Corrêa et al., 2010). An additional benefit of using organic compost to provide nutrients for plant growth is that they provide an alternative for the management and disposal of farm residues.

The growing demand for food produced without the use of pesticides and with respect for the environment is a global trend. In general, consumers are increasingly purchasing natural or organic products and this includes herbal and medicinal plants (Naguib, 2011), which have a growing market, as they are a source of biologically active natural products (Matos and Innecco, 2002).

Mentha arvensis L., popularly known as peppermint or Japanese mint is an aromatic and medicinal plant that belongs to the Lamiaceae family (Lorenzi and Matos, 2002). Its leaves and flowers are rich in essential oils and contain menthol which has great economic importance, especially for the food, cosmetics and pharmaceutical industries (Ram and Kumar, 1997; Simões and Spitzer, 2000), and preparations made with leaves serve as local anesthetics, anti-irritants as relief for headaches and as an antiseptic for the respiratory tract (Kumar et al., 2012). In folk medicine, mint is used in the form of tea for the treatment of gastrointestinal disorders, respiratory and parasitic diseases (Lorenzi and Matos, 2002). Studies have shown that the essential oil is a potential antifungal agent against the human parasite Candida albicans (Lund et al., 2012) and against pathogenic fungi, such as Aspergillus sp., Penicillium rubrum, Fusarium moniliforme (Diniz et al., 2008) and Moniliophthora perniciosa (Chaussê et al., 2011). The economic value of peppermint oil depends on the quality, which is determined by the amount of menthol (Srivastava et al., 2002).

Organic fertilizers are known to play an essential role in many agricultural production systems but there is little information available about the effect of the interaction between organic compost and lime on growth and accumulation of secondary metabolites in medicinal plants. This study thus aimed to evaluate the effect of liming and the application of organic fertilizer on the accumulation of plant biomass, as well as the yield, content and chemical composition of the essential oil of M. arvensis.

\section{MATERIALS AND METHODS}

\section{Experimental conditions}

The experiment was conducted in a greenhouse, under natural light and temperature, from May to September, 2011 using a typical dystrophic Ultisol (surface layer) that had the following characteristics: $\mathrm{pH}\left(\mathrm{CaCl}_{2}\right)=3.9$, organic matter content $=58 \mathrm{~g} \mathrm{dm}^{-}$ ${ }^{3}, \mathrm{P}$ (in resin) $=5 \mathrm{mg} \mathrm{dm}^{-3}, \mathrm{~K}, \mathrm{Ca}, \mathrm{Mg}, \mathrm{Al}, \mathrm{SB}$ and CEC $\left(\mathrm{mmol} \mathrm{dm}^{-3}\right)$ $=0.4,4,4,5.42,8.4$ and 72.7, Cu, Fe, $\mathrm{Zn}, \mathrm{Mn}$ and $\mathrm{B}\left(\mathrm{mg} \mathrm{dm}^{-3}\right)=$ $0.7,88,1.7,0.7,0.34$. The texture of this sandy soil was as follows $\left(\mathrm{g} \mathrm{kg}^{-1}\right)$ : coarse sand (142), fine sand (720), silt (13) and clay (125). The experiment was arranged in a double factorial design with four doses of limestone $\left(0.0,0.25,2.0\right.$ and $3.72 \mathrm{~g} \mathrm{dm}^{-3}$, corresponding to $\mathrm{pH} \mathrm{4,5,6}$ and 7, respectively) and five doses $(0,5,10,20$ or $40 \mathrm{~g}$ $\mathrm{dm}^{-3}$ ) of organic compost previously prepared with sheep manure and straw of Brachiaria humidicola that had the following attributes: $\mathrm{pH}\left(\mathrm{CaCl}_{2}\right)=8.9 ; \mathrm{P}, \mathrm{K}, \mathrm{Ca}, \mathrm{Mg}$ and $\mathrm{S}\left(\mathrm{g} \mathrm{kg}^{-1}\right)=11.7,21.6,32.2,8.0$ and 5.3, respectively; $\mathrm{Cu}, \mathrm{Mn}, \mathrm{Zn}, \mathrm{Fe}$ and $\mathrm{B}\left(\mathrm{mg} \mathrm{kg}^{-1}\right)=57,185$, 195, 7656 and 16, respectively. Doses of the organic compost were defined from concentration of $\mathrm{K}$ in menthe leaves obtained by Garlet and Santos (2008), while doses of limestone were defined from a previously incubation curve using experimental soil. Dolomitic limestone was applied twenty days prior to seedling transplantation into $5 \mathrm{dm}^{3}$ plastic pots that were irrigated regularly with deionized water.

\section{Plant harvest}

The plants were harvested at 115 days after transplanting and separated into leaves, stems and roots, dried in a forced circulation oven at $70^{\circ} \mathrm{C}$ and finally weighed to obtain the total plant and leaf dry biomass.

\section{Content, yield and composition of essential oil}

For essential oil evaluation, samples of dry leaves of each treatment were dried at $40^{\circ} \mathrm{C}$ and then submitted to extraction processes by hydro distillation in a modified Clevenger apparatus for one hour using $10 \mathrm{~g}$ of dry leaves in $1 \mathrm{~L}$ flasks containing $400 \mathrm{ml}$ of distilled water. Quantitative analysis of the essential oil was performed on a Varian saturn 3800 gas chromatograph equipped with a flame ionization detector (FID), using a fused silica capillary column $(30 \mathrm{~m} \times 0.25 \mathrm{~mm} \times 0.25 \mu \mathrm{m})$ with stationary phase VF5-ms $(0.25 \mathrm{~mm}$ thick film). Helium was used as carrier gas with a flow rate of $1.2 \mathrm{ml} / \mathrm{min}$. The temperature of the injector and detector were 250 and $280^{\circ} \mathrm{C}$, respectively. The temperature of the column at the start of the analysis was $70^{\circ} \mathrm{C}$ and increased by $8^{\circ} \mathrm{C}$ per min to $200^{\circ} \mathrm{C}$ followed by an increase at 10 to $260^{\circ} \mathrm{C}$ and maintained at this temperature for $5 \mathrm{~min}$. A solution $(1 \mu \mathrm{l})$ containing essential oils in $10 \%$ chloroform was injected with a split ratio of $1: 10$. The identification of compounds (NIST08 database) was performed using a Agilent $5975 \mathrm{C}$ mass spectrometer operated with an electron impact ionization at $70 \mathrm{eV}$ using a DB-5 column $(30 \mathrm{~m} \times$ $0.25 \mathrm{~mm} \times 0.25 \mathrm{mM}$ ) and injector temperature of $250^{\circ} \mathrm{C}$ under the same conditions used in quantitative analyzes. 

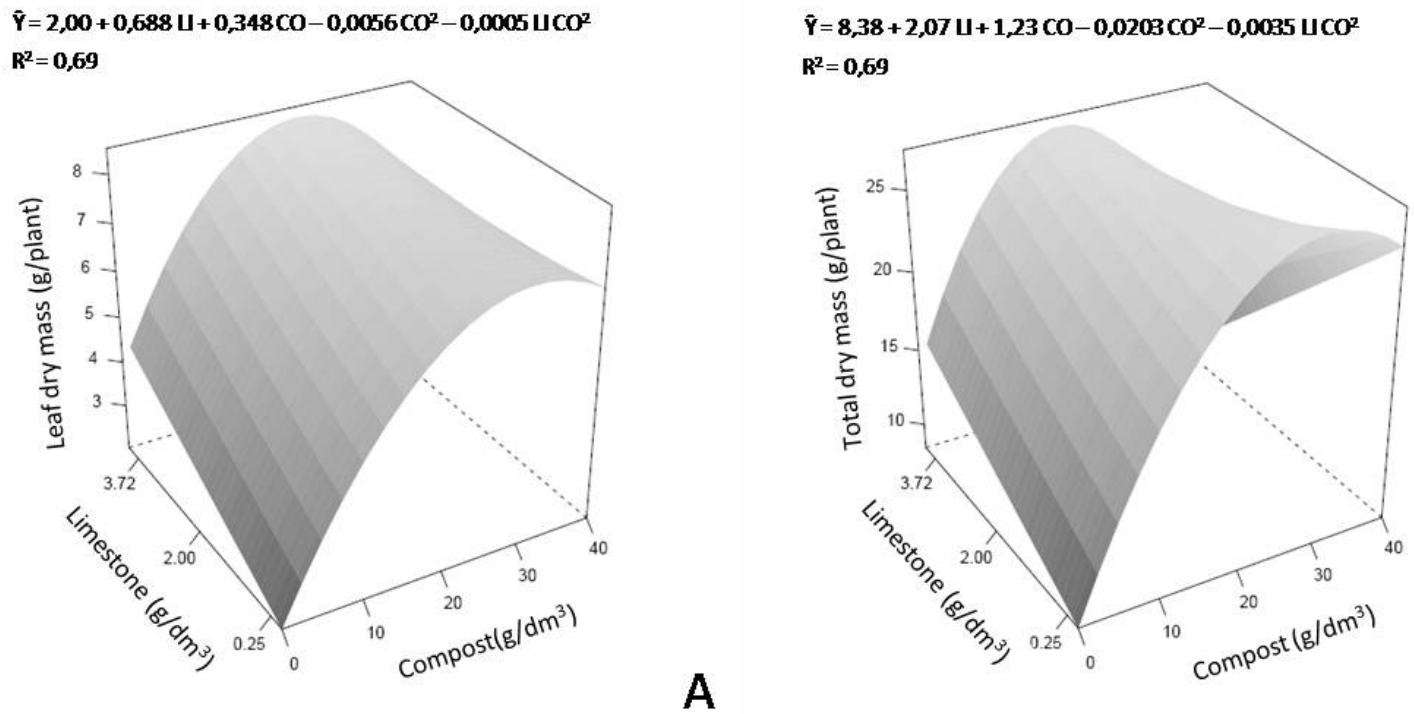

A

Figure 1. Response surface graphs showing interaction effects of limestone and organic compost on the dry mass production of the leaves $(A)$ and of the total plants $(B)$ of Mentha arvensis.

\section{Statistical analyzes}

All data were subjected to analysis of variance considering the completely randomized design with ten replicates, with five repetitions for dry biomass and five for essential oil extraction. The response surface data was adjusted by multiple linear regression equation using the software R.2.15.1.

\section{RESULTS}

\section{Biomass production}

The dry biomass of plants was significantly affected by the interaction between organic compost and limestone doses (Figure 1). The maximum production of dry leaf biomass was $8.61 \mathrm{~g} \mathrm{plant}^{-1}$ with the application of $23.3 \mathrm{~g}$ $\mathrm{dm}^{-3}$ of compost and of $3.72 \mathrm{~g} \mathrm{dm}^{-3}$ of limestone (which is equivalent to $\mathrm{pH}$ 7) (Figure 1A). Similar results were shown for leaf biomass which reached a maximum production of $27.43 \mathrm{~g}$ with the application of $18.5 \mathrm{~g} \mathrm{dm}^{-3}$ compost at the same dose $\left(3.72 \mathrm{~g} \mathrm{dm}^{-3}\right)$ of limestone (Figure 1B).

\section{Content, yield and composition of essential oil}

The essential oil content of $M$. arvensis was affected by fertilization, while the essential oil yield was affected by the interaction between fertilization and liming (Figure 2). Increased levels of organic compost resulted in an increase in the essential oil content of $M$. arvensis. The estimated dose of lime and organic compost applied to the soil to achieve a maximum of $5.47 \%$ essential oil in leaves (Figure 2A) was 29.2 and $2.04 \mathrm{~g} \mathrm{dm}^{-3}$, respectively. With respect to essential oil yield in $M$. arvensis, application of organic compost resulted in maximum production of $0.39 \mathrm{~g} \mathrm{plant}^{-1}$ (Figure 2B) obtained after an interaction of doses of $25.8 \mathrm{~g} \mathrm{dm}^{-3}$ of compost and $1.68 \mathrm{~g} \mathrm{dm}^{-3}$ of limestone.

Analysis of the chemical composition of $M$. arvensis essential oil demonstrated the presence of fourteen components in total (Table 1), twelve of them identified by peak areas in the chromatograms. However, no treatment resulted in all fourteen compounds, with the actual number varying from one to thirteen, depending on the treatment. Clearly, the chemical composition of the essential oil of $M$. arvensis was affected by the treatments, with the number of constituents of the essential oil increasing with organic compost doses (Table 1). Despite this wide variation in compounds within $M$. arvensis essential oil, the major component was neoiso-menthol, which was always present at levels above $89 \%$. In treatments where no organic compost was added to the soil there was a reduced number of constituents (Table 1) and surprisingly, $100 \%$ of neo-iso-menthol (see chromatogram of Figure 3) was recorded with the highest dose of lime $\left(3.72 \mathrm{~g} \mathrm{dm}^{-3}\right)$ in the absence of organic compost.

Treatments resulting in plants with the highest number of essential oil components (13) received an organic compost dose of $20 \mathrm{~g} \mathrm{dm}^{-3}$ with the addition of $2.0 \mathrm{~g} \mathrm{dm}^{-3}$ of limestone. This large diversity in the constituents of the 

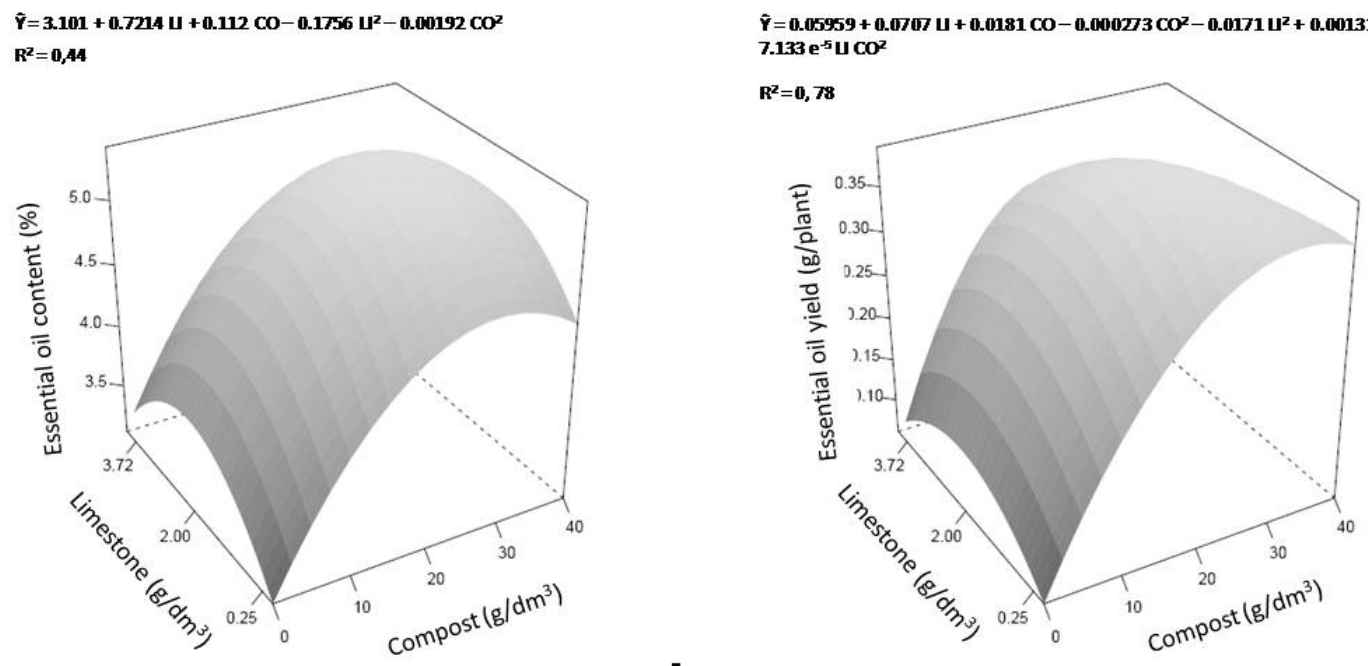

A

Figure 2. Response surface plots showing the effects of limestone and organic compost doses on the essential oil content of leaves (A) and of leaf oil yield (B) of Mentha arvensis.

M. arvensis essential oil did not affect the content of neoiso-menthol, which ranged between 89.35 and $100 \%$ for the various compost and limestone doses.

\section{DISCUSSION}

The pronounced effect of the interaction between organic compost and limestone observed on the growth of $M$. arvensis may be attributed to the increase in soil $\mathrm{pH}$ which contributed to the greater availability of nutrients from compost for the uptake of growing plants. Soil $\mathrm{pH}$ influences nutrient availability and is modified by the application of lime for example, macronutrients tend to be less available in soils with low $\mathrm{pH}$, whereas micronutrients tend to be less available in soils with high pH (Hossain et al., 2011).

The biomass of the $M$. arvensis plants increased accordingly with organic compost fertilization, as same as observed for other studies of medicinal plants, such as Vetiveria zizanioides (Rotkittikhun et al., 2007), Cymbopogon winterianus (Tanu, 2004), Majorana hortensis (Al-Fraihat et al., 2011), Ocimum selloi (Costa et al., 2008), Stevia rebaudiana (Xiangyang et al., 2011), Mentha piperita var. piperita (Pegoraro et al., 2010). The greater dry matter production can be explained by the availability of nutrients due to the increasing doses of organic compost.

The effect of the compost in the presence of lime improves the soil with respect to $\mathrm{pH}$, conductivity, the content of organic matter and the supply of adequate nutrients for better growth and yield (Priyadarshani et al.,
2013). Al-Fraihat et al. (2011) confirmed that the effect of organic fertilizer improves the physical, chemical and biological properties of soils, increasing their cation exchange capacity and water retention, resulting in better plant growth.

The beneficial effect of lime on Melissa officinalis and Mentha piperita was reported by Blank et al. (2006) who showed that a lack of lime, even with $\mathrm{N}$ and $\mathrm{P}$ fertilization, resulted in reductions in leaf production, and the complete omission of liming did not allow for the growth of $M$. officinalis plants. Liming and fertilization were also essential for the growth of Cordia verbenacea (ArrigoniBlank et al., 1999). Souza et al. (2010) reported that soil liming is essential for the development of Lippia citriodora. On the other hand, Sales et al. (2009) did not observe any influence of liming on the accumulation of dry mass of leaves, stems and roots of Hyptis marrubioides. For $M$. arvensis the positive effect of organic fertilization and liming demonstrates that the application of compost and soil amendment should be adopted with the aim of obtaining higher production of the leaves, which are the organs of greatest interest as they contain the active ingredients used by industry.

The content of essential oil in $M$. arvensis leaves verified on our greenhouse experiment can be consider high when comparing with a field experiment using manure fertilization, where Chagas et al. (2011) obtained from 2.83 to $3.14 \%$ of essential oil content in the shoot of $M$. arvensis. On the other hand, working with different doses of industrial $\mathrm{K}$ fertilizer $(\mathrm{KCl})$ in hydroponic conditions, Garlet et al. (2007) reported only 0.79 and $1.07 \%$ of oil content in leaves of $M$. arvensis. The 
Table 1. Kovats indices (IK) and percentage of the chemical constituents of the essential oil of the biomass of the leaves of Mentha arvensis plants submitted to five doses of organic compost and four doses of limestone.

\begin{tabular}{|c|c|c|c|c|c|c|c|c|c|c|c|}
\hline \multirow{2}{*}{ Constituents } & \multicolumn{6}{|c|}{$0 \mathrm{~g} / \mathrm{dm}^{3}$ of limestone } & \multicolumn{5}{|c|}{$0.25 \mathrm{~g} / \mathrm{dm}^{3}$ of limestone } \\
\hline & IK & $\mathrm{CO}$ & $\mathrm{C5}$ & C10 & $\mathrm{C2O}$ & $\mathrm{C} 40$ & $\mathrm{CO}$ & $\mathrm{C} 5$ & $\mathrm{C} 10$ & $\mathrm{C20}$ & $\mathrm{C} 40$ \\
\hline & \multicolumn{11}{|c|}{ Relative percentage (\%) } \\
\hline 3-octanol & & - & - & 0.35 & 0.54 & 0.53 & - & 0.37 & 0.44 & 0.50 & 0.38 \\
\hline Limonene & & - & - & - & - & . & - & - & - & 0.32 & - \\
\hline Linalool & & - & 0.34 & 0.37 & 0.51 & 0.50 & - & 0.38 & 0.45 & 0.51 & 0.51 \\
\hline p-ment-3-enol & & - & 0.55 & 0.37 & 0.38 & 0.37 & - & 0.33 & - & 0.38 & 0.41 \\
\hline Mentone & & - & - & 0.81 & 1.77 & 2.13 & 0.71 & 0.88 & 1.31 & 2.33 & 2.56 \\
\hline Iso-mentone & & - & 1.78 & 1.02 & 1.60 & 1.39 & 0.66 & 1.10 & 1.40 & 1.71 & 1.75 \\
\hline neo-menthol & & 0.39 & - & - & - & - & - & - & - & - & - \\
\hline n.i & & - & - & 0.99 & 1.22 & 1.33 & 0.83 & 1.04 & 1.10 & 1.21 & 1.11 \\
\hline neo-iso-menthol & & 92.57 & 96.29 & 94.95 & 92.81 & 92.66 & 96.68 & 94.44 & 94.20 & 90.68 & 91.02 \\
\hline n.i & & - & - & - & - & - & - & - & - & - & - \\
\hline Piperitone & & - & 0.47 & 0.55 & 0.75 & 0.71 & 0.37 & 0.61 & 0.70 & 0.80 & 0.73 \\
\hline Cariofilene & & - & - & 0.34 & 0.42 & 0.38 & - & 0.38 & 0.40 & 0.44 & 0.47 \\
\hline germacrene & & - & - & 0.25 & - & - & - & - & - & 0.29 & 0.34 \\
\hline di(2-etilexil)phtalate & & 7.04 & 0.57 & - & - & - & 0.75 & 0.46 & - & 0.82 & 0.73 \\
\hline \multirow[t]{3}{*}{ Total (\%) } & & $\begin{array}{c}100.0 \\
0 \\
\end{array}$ & $\begin{array}{c}100.0 \\
0 \\
\end{array}$ & $\begin{array}{c}100.0 \\
0 \\
\end{array}$ & $\begin{array}{c}100.0 \\
0 \\
\end{array}$ & $\begin{array}{c}100.0 \\
0\end{array}$ & 100.00 & 99.99 & 100.00 & 100.00 & 100.00 \\
\hline & \multicolumn{6}{|c|}{$2 \mathrm{~g} / \mathrm{dm}^{3}$ of limestone } & \multicolumn{5}{|c|}{$3.72 \mathrm{~g} / \mathrm{dm}^{3}$ of limestone } \\
\hline & IK & $\mathrm{CO}$ & C5 & C10 & $\mathrm{C2O}$ & $\mathrm{C} 40$ & $\mathrm{CO}$ & $\mathrm{C} 5$ & C10 & $\mathrm{C20}$ & $\mathrm{C} 40$ \\
\hline 3-octanol & 991 & 0.31 & 0.51 & 0.50 & 0.55 & 0.62 & - & 0.48 & 0.51 & 0.58 & 0.47 \\
\hline Limonene & 1031 & - & - & 0.25 & 0.31 & 0.41 & - & - & - & - & - \\
\hline Linalool & 1097 & 0.29 & 0.47 & 0.49 & 0.56 & 0.55 & - & 0.40 & 0.48 & 0.51 & 0.46 \\
\hline p-ment-3-enol & 1149 & 0.32 & 0.36 & 0.38 & 0.47 & 0.39 & - & 0.34 & 0.37 & 0.39 & 0.39 \\
\hline Mentone & 1157 & 0.97 & 1.50 & 2.04 & 2.54 & 3.29 & - & 1.24 & 1.89 & 2.40 & 2.38 \\
\hline Iso-mentone & 1168 & 0.82 & 1.57 & 1.71 & 2.12 & 2.00 & - & 1.22 & 1.56 & 1.67 & 1.55 \\
\hline neo-menthol & 1167 & - & - & - & - & - & - & - & - & - & - \\
\hline n.i & & 0.75 & 1.08 & 1.13 & 1.14 & 1.25 & - & 1.15 & 1.23 & 1.20 & 0.92 \\
\hline neo-iso-menthol & 1178 & 92.95 & 93.40 & 91.53 & 89.66 & 89.35 & 100.00 & 94.18 & 92.45 & 91.49 & 92.86 \\
\hline n.i & & - & - & - & 0.25 & - & - & - & - & - & - \\
\hline Piperitone & 1247 & 0.48 & 0.72 & 0.80 & 0.98 & 0.90 & - & 0.64 & 0.80 & 0.84 & 0.66 \\
\hline Cariofilene & 1424 & 0.27 & 0.39 & 0.45 & 0.56 & 0.42 & - & 0.34 & 0.40 & 0.37 & 0.32 \\
\hline germacrene D & 1485 & - & - & 0.33 & 0.42 & 0.32 & - & - & 0.32 & - & - \\
\hline di(2-etilexil)phtalate & 2553 & 2.85 & - & 0.39 & 0.43 & 0.49 & - & - & - & 0.55 & - \\
\hline Total $(\%)$ & & $\begin{array}{c}100.0 \\
0 \\
\end{array}$ & $\begin{array}{c}100.0 \\
0 \\
\end{array}$ & $\begin{array}{c}100.0 \\
0 \\
\end{array}$ & $\begin{array}{c}100.0 \\
0 \\
\end{array}$ & $\begin{array}{c}100.0 \\
0\end{array}$ & 100.00 & 100.00 & 100.00 & 100.00 & 100.00 \\
\hline
\end{tabular}

IK obtained by capillary column VF5-ms $(30 \mathrm{~m} \times 0,25 \mathrm{~mm} \times 0,25 \mu \mathrm{m})$, with the temperature of the injector and detector at 250 and $280^{\circ} \mathrm{C}$, respectively; ${ }^{* *} \mathrm{ND}=$ not determined; C0, C5, C10,C20 and C40 correspond to 0, 5, 10, 20 e $40 \mathrm{~g} / \mathrm{dm}^{3}$ organic compost dose, respectively, incorporated into soil.

influence of organic fertilization on the content of essential oil can be variable between species for example, Priyadarshani et al. (2013) observed that higher oil content $(3.74 \%)$ was recorded in Vetiveria zizanioides planted with $75 \%$ of organic and $25 \%$ inorganic fertilizer. The leaf oil yield of $M$. arvensis was positively influenced by organic fertilizer as same as reported by Chagas et al.
(2011), with same species and with Ocimum selloi fertilized with cattle manure compost (Costa et al., 2008). The constituents of the $M$. arvensis essential oil are sensitive to environmental changes, especially to stress caused by lack of nutrients. The production of secondary metabolites is regulated by biotic and abiotic factors and is usually drastically altered when the plant is under 


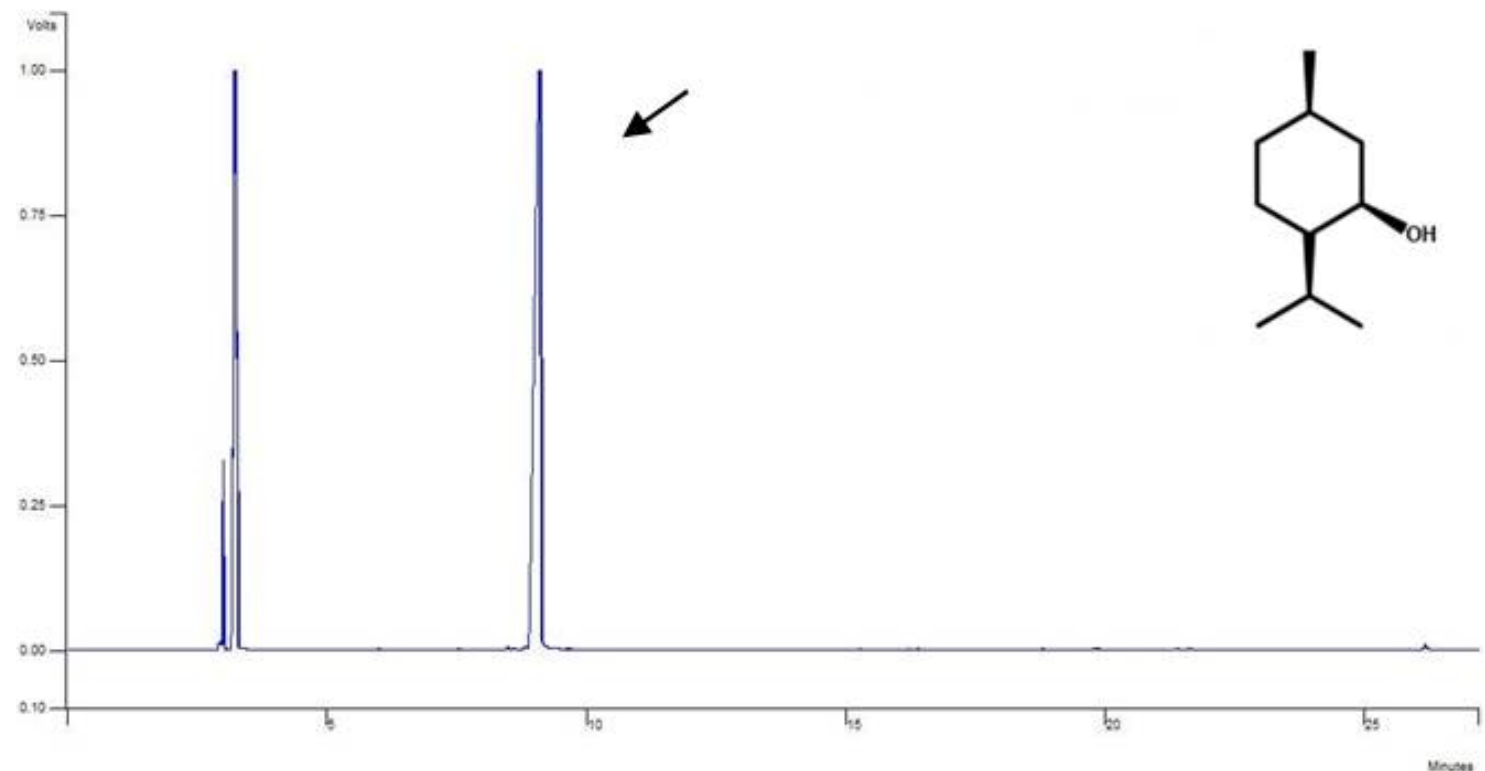

Figure 3. Chromatographic profile of Mentha arvensis essential oil from plants subjected to highest dose of limestone and without organic compost fertilization. GC/MS (Agilent 5975C, $70 \mathrm{eV}$ ), DB-5 (30 m) column. The first peak corresponds to the solvent (chloroform) injected together with the oil sample in the chromatograph, and the second peak (arrow) was identified as iso-neo-menthol.

stress (Farooqi et al., 1999; Patra and Kumar, 2012).

The changes in the composition of essential oil that were mediated by nutritional stress were most prominently reflected in the main oil constituent, neo-isomenthol, which varied with applied limestone doses. We observed that the content of neo-iso-menthol was high, whereas, iso-menthone was low probably because in the final step of reduction via iso-menthone it is reduced to neo-iso-menthol and menthol is a menthone derivative produced by the cytoplasmic enzyme menthone reductase (Davis et al., 2005; Mcgarvey and Croteau, 1995). In Mentha piperita, Gershenzon et al. (2000) observed that the proportions of limonene decreased with plant age, while menthol, neo-menthol substantially increased.

Simoes and Spitzer (2000) stated that approximately $90 \%$ of the volatile oils are composed of terpenes. In our study, $M$. arvensis cultivated under increasing doses of limestone and organic compost gave, in addition to neoiso-menthol as the major compound, other monoterpenes such as limonene, linalool, p-ment-3-enol, menthone, isomenthone, neo-menthol, piperitone and two sesquiterpenes: caryophyllene and germacrene. The monoterpenes are the major components of the essential oil of many species of the genus Mentha (Gershenzon et al., 2000; Mahmoud and Croteau, 2003; Oliveira et al., 2012).

\section{Conclusion}

Liming and organic compost fertilization is essential, not only for biomass accumulation, but also for essential oil production in $M$. arvensis. By applying, on average, 25.8 $\mathrm{g} \mathrm{dm}^{-3}$ of compost and $1.68 \mathrm{~g} \mathrm{dm}^{-3}$ of limestone (equivalent to 51.6 and $3.36 \mathrm{t} \mathrm{ha}^{-1}$, respectively) we obtained high biomass and essential oil production, which are features desirable for the market and for trading.

\section{ACKNOWLEDGEMENTS}

We are grateful to the Centro Mars de Ciências do Cacau for essential oil sample analysis. The financial support granted to P.A.C. Alves was provided by CAPES. We thank Euan K. James for his excellent technical review.

\section{Conflict of Interests}

The author(s) have not declared any conflict of interests.

\section{REFERENCES}

Al-Fraihat AH, Al-dalain SYA, Al-Rawashdeh ZB, Abu-Darwish MS, AlTabbal JA (2011). Effect of organic and biofertilizers on growth, herb yield and volatile oil of marjoram plant grown in Ajloun region, Jordan. J. Med. Plants Res. 5:2822-2833.

Arrigoni-Blank MF, Faquin V, Pinto JEBP, Blank AF, Lameira OA (1999). Adubação química e calagem em erva-baleeira (Cordia verbenacea). J. Braz. Assoc. Horticult. Sci. 17:211-215.

Blank AF, Oliveira AS, Arrigoni-Blank MF, Faquin V (2006). Efeitos da adubação química da calagem na nutrição de melissa e hortelã pimenta. J. Braz. Assoc. Horticult. Sci. 24:195-198. 
Brant RS, Pinto JEBP, Bertolucci SKV, Albuquerque CJB (2010). Produção de biomassa e teor do óleo essencial de cidrão em função da adubação orgânica. J. Braz. Assoc. Horticult. Sci. 28:111-114.

Chagas JH, Pinto JEBP, Bertolucci SKV, Santos FM, Botrel PP, Pinto LBB (2011). Produção da hortelã-japonesa em função da adubação orgânica no plantio e em cobertura. J. Braz. Assoc. Horticult. Sci. 29:412-417

Chaussê TCC, Dias DBS, Silva SDVM, Costa JCB, Costa LCB (2011). Atividade antifúngica de óleos essenciais sobre a vassoura de bruxa do cacaueiro. Braz. J. Biosci. 9:492-496.

Corrêa RM, Pinto JEBP, Reis ES, Costa LCB, Alves PB, Niculau ES, Brant RS (2010). Adubação orgânica na produção de biomassa de plantas, teor e qualidade de óleo essencial de orégano (Origanum vulgare L.) em cultivo protegido. Rev. Bras. Plant Med. 12:80-89.

Costa LCB, Pinto JEBP, Bertolucci SKV, Cardoso MG (2007). Produção de biomassa e óleo essencial de elixir-paregórico em função do corte das inflorescências e épocas de colheita. J. Braz. Assoc. Horticult. Sci. 25:175-179.

Costa LCB, Pinto JEBP, Castro EM, Bertolucci SKV, Corrêa RM, Reis ES, Alves PB, Niculau ES (2008). Tipos e doses de adubação orgânica no crescimento, no rendimento e na composição química do óleo essencial de elixir paregórico. Cienc. Rural 38:2173-2180.

Davis EM, Ringer KL, McConkey ME, Croteau R (2005). Monoterpene metabolism cloning, expression, and characterization of menthone reductases from peppermint. J. Plant Physiol.137:873-881.

Diniz SPSS, Coelho JS, Rosa GS, Specian V, Oliveira RC, Oliveira RR (2008). Bioatividade do óleo essencial de Mentha arvensis L. no controle de fungos fitopatógenos. Rev. Bras. Plant Med. 10:9-11.

Duarte MCT, Figueira GM, Sartoratto A, Rehder VLG, Delarmelina C (2005). Anti-Candida activity of Brazilian medicinal plants. J. Ethnopharmacol. 97:305-311.

Farooqi AHA, Sangwan NS, Sangwan RS (1999). Effect of different photoperiodic regimes on growth, flowering and essential oil in Mentha species. Plant Growth Regul. 29:181-187.

Garlet TMB, Santos OS (2008). Solução nutritiva e composição mineral de três espécies de menta cultivadas no sistema hidropônico. Cienc. Rural 38:1233-1239.

Garlet TMB, Santos OS, Medeiros SLP, Manfron PA, Garcia DC, Sinchak SS (2007). Crescimento e teor de óleo essencial de mentas com diferentes concentrações de potássio na solução nutritiva. J. Braz. Assoc. Horticult. Sci. 25:230-237.

Gershenzon J, Mcconkey ME, Croteau RB (2000). Regulation of monoterpene accumulation in leaves of peppermint. J. Plant Physiol. 122:205-214.

Hendawy SF (2008). Comparative study of organic and mineral fertilization on Plantago arenaria plant. J. Appl. Sci. Res. 4:500-506.

Hossain A, Sarker MAZ, Hakim MA, Islam MT, Ali ME (2011). Effect of lime, magnesium and boron on wheat (Triticum aestivum L.) and their residual effects on mungbean (Vigna radiata L.). IJARIT. 1:1-2.

Karlen DL, Eash NS, Unger PW (1992). Soil and crop management effects on soil quality indicators. Am. J. Alt. Agric. 7:48-55.

Kumar KV, Patra DD (2012). Alteration in yield and chemical composition of essential oil of Mentha piperita L. plant: Effect of fly ash amendments and organic wastes. Ecol. Engine. 47:237- 241.

Kumar A, Khajuria V, Aggarwal S (2012). Secondary metabolites of Mentha arvensis and their biological activities. Anal. Chem. Lett. 2:373-400.

Lorenzi H, Matos FJA, (2002). Plantas medicinais no Brasil: nativas e exóticas, Instituto Plantarum, Nova Odessa, 254p.

Lund RG, Serpa R, Nascente PS, Ribeiro GA, Freitag RA, Pino FABD (2012). In vitro study on the antimicrobial effect of hydroalcoholic extracts from Mentha arvensis L. (Lamiaceae) against oral pathogens. Acta Sci. Biol. Sci. 34:437- 442.
Mahmoud SS, Croteau RB (2003). Menthofuran regulates essential oil biosynthesis in peppermint by controlling a downstream monoterpene reductase. Proc. Natl. Acad. Sci. USA 24:14481-14486.

Mattos SH, Innecco R (2002). Idade ideal de corte da Mentha arvensis L. como produtora de óleo essencial e mentol para o Estado do Ceará, Brasil. Rev. Bras. Plant Med. 5:15-18.

Mcgarvey DJ, Croteau R (1995). Terpenoid metabolism. Plant Cell. 7:1015-1026.

Naguib NYM (2011). Organic vs chemical fertilization of medicinal plants: a concise review of researches. Adv. Environ. Biol. 5:394-400.

Oliveira ARMF, Jezler CN, Oliveira RA, Mielke MS, Costa LCB (2012). Determinação do tempo de hidrodestilação e do horário de colheita no óleo essencial de menta. J. Braz. Assoc. Horticult. Sci 30:155159.

Pegoraro RL, Falkenberg MB, Voltolini CH, Santos M, Paulilo MTS (2010). Produção de óleos essenciais em plantas de Mentha x piperita L. var. piperita (Lamiaceae) submetidas a diferentes níveis de luz e nutrição do substrato. Rev. Bras. Bot. 33:631-637.

Priyadarshani NDN, Amarasinghe MKTK, Subasinghe S, Palihakkara I R, Kumarasinghe HKMS (2013). Effect of organic and inorganic fertilizers on biomass production, oil yield and quality of vetiver (Vetiveria zizanioides L.). J. Agric. Sci. 8:28-35.

Ram M, Kumar S (1997). Yield improvement in the regenerated and transplanted mint Mentha arvensis by recycling the organic wastes and manures. Bioresour. Technol. 59:141-149.

Rosal LF, Pinto JEBP, Bertolucci SKV, Brant RS, Niculau ES, Alves PB (2011). Produção vegetal e de óleo essencial de boldo pequeno em função de fontes de adubos orgânicos. Rev. Ceres 58:670-678.

Rotkittikhun P, Chaiyarat R, Kruatreehue M, Pokethitiyook P, Baker A (2007). Growth and lead accumulation by grasses Vetiveria zizanioides and Thysanolaena máxima in lead-contaminated soil amended with pig manure and fertilizer: A glasshouse study. Chemosphere 66:45-53.

Sales JF, Pinto JEBP, Botrel PP, Silva FG, Correa RM, Carvalho JG (2009). Acúmulo de massa, teor foliar de nutrientes e rendimento de óleo essencial de hortelã-do-campo (Hyptis marrubioides EPL.) cultivado sob adubação orgânica. Biosci. J. 25:60-68.

Simões CMO, Spitzer V (2000). Óleos voláteis, In: Simões CMO, Schenkel EP, Gosmann G, Mello JCP de, Mentz LA, Petrovick PR (eds) Farmacognosia: da planta ao medicamento, Florianópolis, Porto Alegre: UFRGS / UFSC, pp. 387-416.

Souza MF, Souza Junior IT, Gomes PA, Fernandes LA, Martins ER, Costa CA, Sampaio RA (2010). Calagem e adubação orgânica na produção de biomassa e óleo essencial em Lippia citriodora Kunth. Rev. Bras. Plant Med. 12:401-405.

Srivastava RK, Singh AK, Kalra A, Tomar VKS, Bansal RP, Patra DD, Chand S, Naqvi AA, Sharma S, Kumar S (2002). Characteristics of menthol mint Mentha arvensis cultivated on industrial scale in the Indo-Gangetic plains. Ind. Crop Prod. 15:189-198.

Tanu, Prakash A, Adholeya A (2004). Effect of different organic manures/composts on the herbage and essential oil yield of Cymbopogon winterianus and their influence on the native AM population in a marginal alfisol. Bioresour. Technol. 92-97.

Xiangyang L, Guangxi R, Yan S (2011). The effect of organic manure and chemical fertilizer on growth and development of Stevia rebaudiana Bertoni. Energy Procedia 5:1200-1204. 